\title{
Pemanfaatan Pakan Komplit Berbasis Limbah Sawit untuk Usaha Penggemukan Sapi Kurban di Kelompok Tani Ternak Sumber Rezeki
}

\author{
(Utilization Of Complete Feed Base Oil Palm Waster For Kurban Fattening On \\ Kelompok Tani Ternak Sumber Rezeki)
}

\author{
Nurhaita*, Neli Definiati dan Rita Feni \\ Fakultas Pertanian Universitas Muhammadiyah Bengkulu Jl. Bali No 118 Bengkulu 38119 \\ *Penulis Korespondensi: nurhaita@gmail.com
}

\begin{abstract}
The main problem of partnership is the difficulty of supplying green feed. Palm oil frond was the most available palm oil waste for feed utilization by partnership because partner was located in palm oil plantation area. In addition solid CPO mills waste is also available near the locations. For optimum feed utilization, palm oil waste was to undergo particular process through fermentation with MOL (local microorganism) derivate from rument content. The objective of this activity was to introduce the processing technology of palm oil waste by fermentation to partner group. The product of this activity are fermented palm oil frond, fermented solid and mol from rument content. These community service activities are carried out using counseling, training and demonstration methods, as well as group guidance and assistance. As a result of this activity the partner group is able and skilled at processing palm fronds and solids by fermentation and can also make MOL from rumen contents to be used as a starter in fermentation. The fermented palm waste produced is of good quality with fragrant odor characteristics such as tape, a yellowish green color that is not moldy and not slimy. Fermented palm oil waste has quite good palatability. It can be seen from the response of cattle when the new feed is served, cattle are immediately willing to consume them without the need for long adaptations. In Conclusion palm oil waste processing technology can be well accepted and has been applied to partner groups as solution to the forage feed problem
\end{abstract}

Key words: fermentation, mol rument content, oil palm waste, kurban fattening

\section{PENDAHULUAN}

Kelompok Tani Ternak Sumber Rezeki di Desa Bukit Peninjauan 1 Kecamatan Sukaraja Kabupaten Seluma adalah salah satu kelompok tani yang focus pada usaha penggemukan sapi kurban. Produk yang dihasilkan oleh mitra berupa sapi potong untuk kurban. Pemasaran produk ini hampir tidak mengalami kendala. Pada saat Idul Adha panitia kurban dari mesjid-mesjid disekitar Bengkulu akan datang membeli sapi untuk qurban di mesjid mereka. Harga jual ternak sapi kurban juga relatif stabil bahkan cenderung naik setiap tahun. Permintaan sapi kurban di kelompok ini terus meningkat dari tahun ke tahun.

Kendala utama yang dihadapi oleh mitra kesulitan pakan hijauan. Hal ini disebabkan semakin berkurangnya lahan yang tersedia bagi penanaman hijauan terutama rumput karena peralihan fungsi lahan untuk pemukiman, pertanian tanaman pangan dan perkebunan. Ketersediaan pakan hijauan khususnya rumput semakin sulit, terutama pada musim tanam dan musim penghujan. Pada musim tanam rumput seringkali di semprot oleh petani untuk membersihkan lahan dan persiapan lahan, sedang pada musim hujan jalan ke lokasi sumber pakan sulit ditempuh karena becek dan berlumpur. Selama ini 
hijauan yang berikan hanya berupa rumput alam dengan campuran semak yang kualitas dan kuantitas yang rendah.

Pelepah sawit merupakan limbah kebun sawit yang paling tersedia untuk dimanfaatkan sebagai pakan ternak dikelompok mitra, karena desa ini berada diareal perkebunan sawit yang sangat luas. Beberapa hasil penelitan terdahulu menyatakan bahwa pelepah dan daun sawit dapat diberikan sebagai pengganti rumput pada ternak domba (Nurhaita et, al. 2008; 2010) dan pada ternak sapi (Djajanegara et al., 1999 ; Nurhaita et al., 2014). Meskipun daun sawit tersedia cukup banyak, namun pemanfaatannya sebagai pakan ternak masih sangat terbatas, sebagian besar masih terbuang atau ditumpuk di bawah batang sawit. Pelepah sawit merupakan pakan limbah yang berkualitas rendah, nilai gizinya rendah, fraksi seratnya tinggi, palatabilitas dan kecernaannya rendah. Untuk dapat dimanfaatkan secara optimal sebagai pakan ternak pelepah sawit harus diolah terlebih dahulu. Penggunaan pelepah sawit yang belum diolah tidak dapat memenuhi kebutuhan ternak, bahkan bila digunakan dalam jumlah banyak dapat menurunkan performa ternak. Pengolahan secara fisik, kimia dan biologis mampu meningkatkan nilai gizi dan kecernaan pelepah sawit (Nurhaita et al. 2007). Cara pengolahan yang mudah, murah dan ramah lingkungan adalah secara fermentasi dengan menggunakan MOL.

Selain pelepah sawit, terdapat pula solid yang merupakan limbah pabrik CPO yang ada di daerah ini. Bentuk dan konsistensinya seperti ampas tahu namun berwarna coklat gelap. Bahan limbah ini mengandung protein kasar (PK) 12,6317,41\%; serat kasar (SK) 9,98-25,79\%; lemak kasar (LK) 7,12-15,15\%; energi bruto 3.217-3.454 Kkal/kg dan CPO 1,5\% Solid dapat digunakan sebagai pakan ternak ruminansia (Utomo dan Widjaja, 2004). Pada kondisi umum solid sangat mudah rusak, berjamur dan berulat, sehingga perlu perlakuan fermentasi untuk memperpanjang masa simpannya.

Pemanfaatan pakan komplit limbah sawit pada usaha penggemukan sapi kurban di kelompok mitra ini merupakan aplikasi dari hasil penelitian tersebut. Kelompok mitra dilatih mengolah pelepah sawit dan solid fermentasi dan memformulasikannya menjadi pakan komplit. Pendampingan pada kelompok mitra akan dilakukan selama satu periode penggemukan sapi yaitu 6-8 bulan.

Fermentasi adalah proses pengolahan bahan dengan bantuan mikroba yang mampu memecah komponen komplek menjadi bentuk yang lebih sederhana, misalnya selulosa dan hemiselulosa menjadi glukosa. Bahan yang mengalami fermentasi biasanya mempunyai nilai gizi yang lebih baik dari asalnya. Hal ini tidak hanya disebabkan oleh mikroorganisme yang memecah komponenkomponen komplek menjadi zat-zat yang sederhana sehingga mudah dicerna, tetapi mikroorganisme juga dapat mensintesa beberapa vitamin seperti riboflavin, vitamin B 12, pro vitamin A dan faktor pertumbuhan lainnya, juga dapat terjadi pemecahan karbohidrat oleh enzim tertentu misalnya hemisellulosa, sellulosa dan polimerpolimernya menjadi gula sederhana atau turunannya (Winarno et al. 1980).

Fermentasi dapat memperbaiki sifat tertentu dari bahan seperti menjadi lebih mudah dicerna, lebih tahan disimpan dan dapat menghilangkan senyawa racun yang terkandung di dalammya, sehingga nilai ekonomis bahan dasarnya menjadi lebih baik Selain itu fermentasi juga dapat meningkatkan kandungan protein bahan karena adanya berbagai jenis mikroorganisme yang mempunyai kemampuan untuk mengkonversi pati menjadi protein dengan penambahan nitrogen anorganik (Laelasari dan Purwadaria, 2004).

Teknologi fermentasi merupakan salah satu alternatif solusi dalam pemanfaatan bahan baku pakan lokal secara optimal (Pamungkas, 2011). Hasil penelitian menunjukkan bahwa daun sawit dan pelepah sawit yang telah diolah secara amoniasi dan fermentasi dapat dijadikan pengganti $100 \%$ rumput pada pakan ternak domba dan sapi dan memberikan pengaruh yang sama dengan rumput jika disuplementasi dengan mineral S dan $\mathrm{P}$ serta daun ubi kayu (Nurhaita, 2008; Nurhaita et al. 2010 dan Nurhaita et al. 2011).

Mikrorganisme lokal (MOL) merupakan hasil fermentasi dari berbagai 
bahan limbah. Keunggulan penggunaan MOL yang paling utama adalah murah bahkan tanpa biaya karena MOL dapat dibuat dari buah-buahan dan sayur-sayuran yang sudah busuk dan terbuang, limbah ternak, limbah rumah potong ataupun limbah rumah tangga, serta mudah dalam proses pembuatannya dan bersifat aplikatif. MOL adalah larutan yang mengandung bakteri dan jamur yang berpotensi sebagai perombak bahan organik. Hasil identifikasi bakteri dari Lab. LIPI diketahui MOL dari isi rumen berisikan 5 species basilus yaitu $B$. aerius, B. altitudinis, B. cereus, Bacillus sp, dan B. megaterium.

Fermentasi kulit pisang dengan MOL yang dibuat dari berbagai bahan limbah mampu meningkatkan nilai nutrisi dan kecernaan kulit pisang (Astuti dan Yurni, 2012) dan Pod kakao (Nurhaita et al 2016). Penggunaan MOL pada fermentasi pelepah sawit juga mampu meningkatkan kualitas pelepah sawit sehingga dapat dijadikan pakan hijauan pengganti rumput.

\section{METODE PELAKSANAAN PKM}

PKM dilaksanakan selama 8 bulan dari Maret sampai dengan Oktober 2019 di Kelompok Tani Ternak Sumber Rezeki Desa Bukit Peninjauan $1 \mathrm{Kec}$. Sukaraja Kabupaten Seluma. Kegiatan dilakukan dengan beberapa metoda yaitu penyuluhan, pelatihan dan demonstrasi, dan pendampingan pada kelompok mitra. Kegiatan ini selain diikuti oleh anggota kelompok juga diikuti oleh mahasiswa dari prodi peternakan Universitas Muhammadiyah Bengkulu.

Tahapan pelaksanaan kegiatan pengabdian adalah :

A. Tahap Persiapan

1. Koordinasi dengan kelompok mitra

2. Sosialisasi program PKM pada kelompok mitra

B. Tahap Pelaksanaan

Pelaksanaan program PKM di kelompok mitra dilakukan dengan metoda:

1. Penyuluhan; dilakukan dengan metode ceramah dan diskusi, bertujuan untuk meningkatkan pengetahuan anggota Kelompok Tani tentang berbagai aspek peternakan terutama tentang pakan.

2. Pelatihan dan demonstrasi cara pembuatan pembuatan pelepah sawit fermentasi, Solid fermentasi menjadi pakan ternak dan pembuatan MOL dari isi rumen.

3. Pendampingan kelompok; dilakukan selama program PKM dalam hal pengolahan pelepah sawit dan solid menjadi pakan ternak dan pemberian pakan limbah sawit olahan pada ternak kelompok mitra.

C. Monitoring dan Evaluasi; secara internal dilakukan oleh pihak LPPM UMB dan secara eksternal dilakukan oleh reviewer Dikti.

D. Pelaporan; berupa laporan kemajuan (70\%) dan laporan akhir (100\%)

\section{HASIL DAN PEMBAHASAN}

Kegiatan diawali dengan melakukan koordinasi dengan kelompok tani mitra, dilanjutkan dengan sosialisasi program. Pada kegiatan awal disepakati bersama program yang akan dilaksanakan dan jadwal pelaksanaannya.

Program pertama kegiatan ini adalah penyuluhan yang diikuti oleh semua anggota kelompok mitra. Kegiatan ini mampu meningkatkan pengetahuan dan motivasi anggota kelompok mitra, hal ini terlihat pada antusiasnya peserta pada sesi diskusi dan tanya jawab.

Materi penyuluhan antara lain :

a. Pentingnya pakan berkualitas pada ternak sapi potong untuk menunjang produktifitas ternak

b. Penyuluhan tentang bahan pakan untuk ternak sapi, meliputi hijauan pakan, bahan-bahan limbah pertanian yang dapat dijadikan pakan ternak sapi dan teknik penyusunan ransum untuk ternak sapi potong.

c. Pelepah sawit sebagai sumber pakan hijauan dan pentingnya pengolahan pelepah sawit sebelum diberikan pada ternak.

Meskipun materi penyuluhan telah disiapkan sesuai dengan program kegiatan, namun dalam sesi diskusi dan tanya jawab terbuka pula kemungkinan untuk menambahkan materi lain seperti tentang manajemen, penanganan kesehatan dan 
penyakit, masalah IB, penangan limbah, pengolahan pasca panen, peluang usaha dan

lain-lain sesuai dengan pertanyaan yang

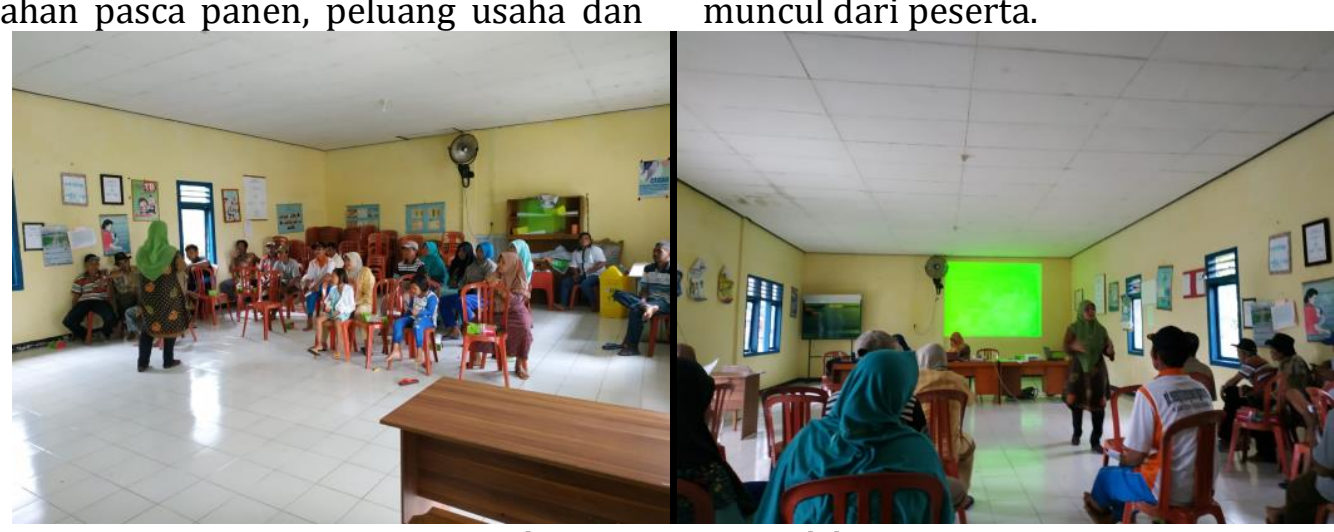

Gambar 1. Suasana Penyuluhan

\subsection{Pelatihan dan Demonstrasi}

Pelatihan dan demontrasi pengolahan pelepah sawit dan solid menjadi pakan ternak sapi dilakukan sebanyak tiga kali. Hasil dari kegiatan ini

1. Kelompok mitra mampu membuat MOL dari isi rumen dan menggunakan MOL untuk sumber inokulum dalam fermentasi pelepah sawit dan solid

2. Kelompok mitra terampil mengolah pelepah sawit fermentasi
3. Dan terampil mengolah solid fermentasi.

Pembuatan MOL dilakukan dengan bahan dari limbah air kelapa, molases dan isi rumen sebagai sumber mikroba. Isi rumen merupakan limbah rumah potong yang mengandung banyak mikroba pencerna serat. Dengan demikian diharapkan MOL yang berkembang mengandung mikroba pencerna serat yang efektif. Hasil MOL yang diperoleh pada kegiatan ini berbau harum seperti tape.

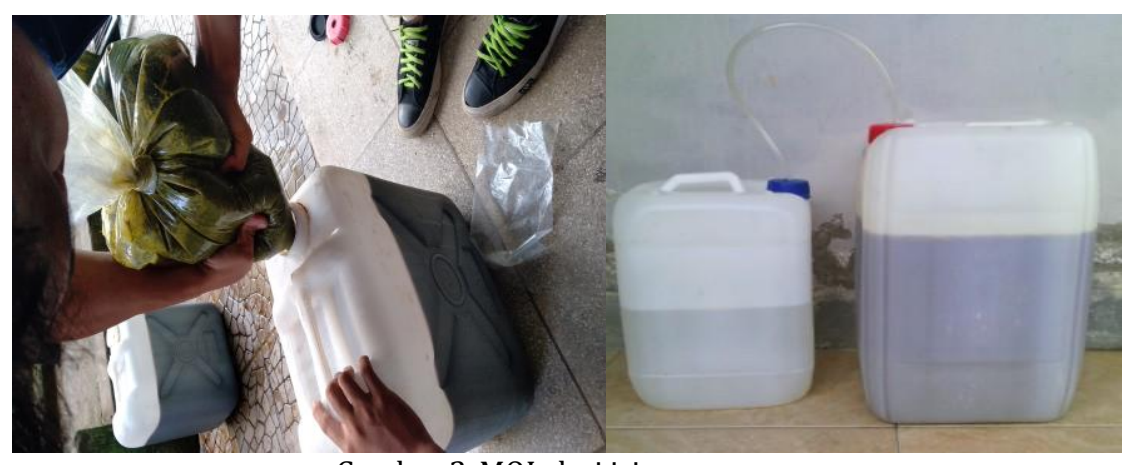

Gambar 2. MOL dari isi rumen

Fermentasi pelepah sawit dilakukan dengan menggunakan MOL sebagai starter. Sebagai additif ditambah molases, urea dan dedak. Proses fermentasi berlangsung selama 7 hari. Hasil fermentasi berkualitas baik dengan ciri-ciri aromanya harum seperti tape, berwarna hijau kekuningan, teksturnya masih utuh, tidak berjamur dan tidak berlendir. 


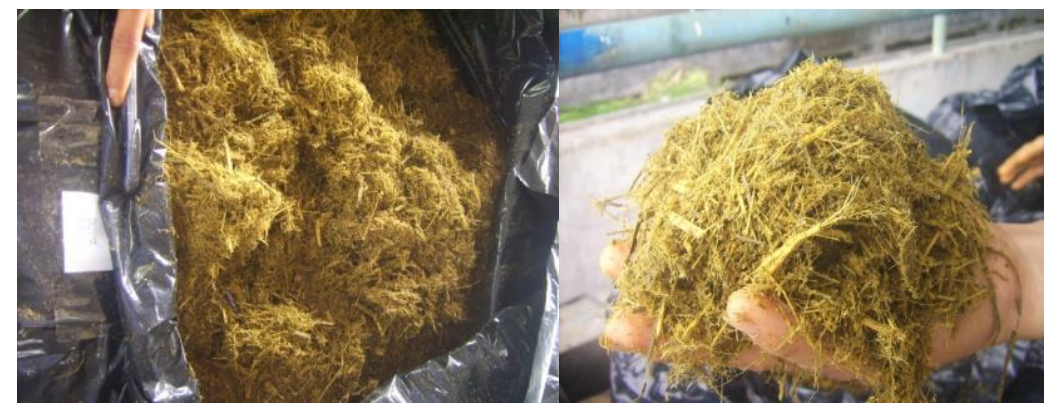

Gambar 3. Pelepah Sawit Fermentasi

Pembuatan fermantasi solid selain menggunakan MOL dari isi rumen sebagai starter juga ditambahkan kapur, garam, urea dan molases. Fermentasi secara anaerobik berlangsung selama 7 hari. Hasil fermenatsi berkualitas baik dengan ciri-ciri baunya harum, warna coklat, tidak berjamur dan tidak ada belatung.
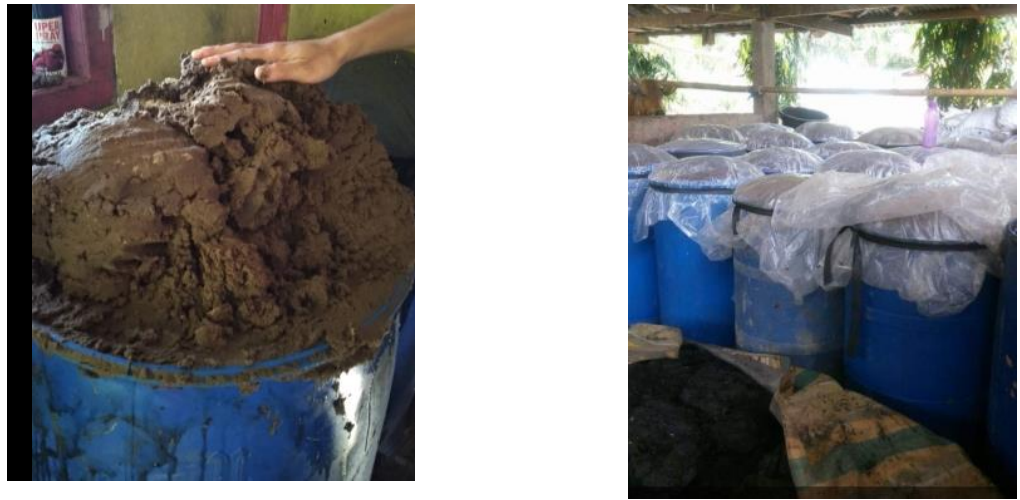

Gambar 4. Fermentasi Solid

\subsection{Bimbingan dan Pendampingan}

Kegiatan

pendampingan

dilakukan

bimbingan

dan

pendampingan dilakukan pat pengolahan limbah sawit secara mandiri oleh kelompok mitra dan pemberian pakan limbah sawit olahan pada ternak. Pembiasaan/ adaptasi terhadap pakan limbah sawit fermentasi dilakukan dengan cara :

1. Memberikan hijauan berupa rumput yang dicampur dengan pelepah sawit olahan dengan cara mengganti sebagian rumput dengan pelepah sawit olahan secara bertahap sampai proporsi pelepah sawit lebih banyak dari rumput atau bisa menggantikan rumput.

2. Memerciki pakan pelepah sawit olahan dengan air garam atau air gula untuk meningkatkan palatabilitasnya. Kegiatan bimbingan dan pendampingan kelompok mitra dilakukan setelah pelatihan pengolahan pelepah sawit dan solid. Selama 5 bulan tim PKM selalu datang ke kelompok mitra setiap bulan untuk mendampingi kelompok dalam pengolahan pelepah sawit dan solid. Pelepah sawit dan solid hasil fermentasi bisa langsung diberikan pada

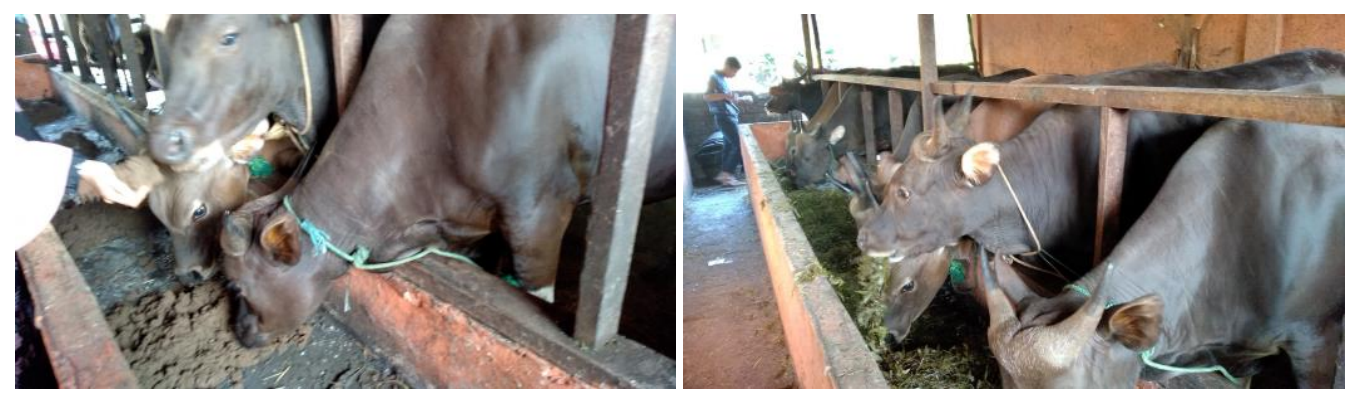

Gambar 6. Percobaan Pemberian limbah Sawit Fermentasi pada Ternak Sapi 
Hasil pengamatan selama masa pendampingan terlihat pakan pelepah sawit dan solid fermentasi sangat disukai ternak dan mempunyai palatabilitas yang tinggi, terlihat ternak sapi langsung mau mengkonsumsi pakan baru yang disajikan tanpa harus diadaptasikan dalam waktu lama. Hal ini disebabkan pelepah sawit dan solid fermentasi yang dihasilkan mempunyai aroma yang harum dan merangsang nafsu makan. Dari hasil penimbangan ternak diketahui bahwa pertambahan bobot badan sapi yang mengkonsumsi ransum limbah sawit fermentasi ini cukup tinggi yaitu ratarata $720 \mathrm{gr} /$ ekor/hari.

\section{KESIMPULAN}

Teknologi fermentasi yang diajarkan pada kelompok mitra untuk pengolahan limbah sawit dapat diterima dengan baik dan telah diaplikasikan pada kelompok mitra. Pakan limbah sawit olahan cukup disukai ternak dapat menjadi solusi dalam masalah kesulitan pakan hijauan.

\section{UCAPAN TERIMA KASIH}

Terimakasih disampaikan pada DRPM Ristekdikti yang telah mendanai kegiatan pengabdian ini melalui skema Program Kemiteraan Masyarakat (PKM) tahun anggaran 2019. Terimaksih juga disampaikan pada Kelompok Tani Sumber Rezeki sebagai mitra dalam kegiatan PKM ini dan LPPM Universitas Muhammadiyah Bengkulu yang telah memberikan dukungan pada pelaksanaan kegiatan ini

\section{DAFTAR PUSTAKA}

Astuti, Tri., dan Yurni, S.A. 2012. Bioproses Optimalisasi Pemanfaatan Kulit Pisang dengan menggunakan Mikroorganisme Lokal (MOL) Sebagai Pakan Ternak Ruminansia. Laporan Hibah bersaing 2012. Universitas Muaro Bungo. Jambi

Djajanegara, A. B., Sudaryanto. M., Winugroho dan A. R. A. Karto. 1999. Potensi produk kebun kelapa sawit untuk pengembangan usaha ternak ruminansia. Laporan APBN 1998/1999. Balai Penelitian Ternak, Puslitbang Peternakan, Bogor

Laelasari \& Purwadaria, T. 2004. Pengkajian nilai gizi hasil fermentasi mutan aspergillus niger pada subtrat bungkil kelapa dan bungkil inti sawit. Biodiversitas, 5(2): 48-51

Nurhaita, N. Jamarun, R. Saladin, L Warly dan Mardiati Z. 2007. Efek beberapa metoda pengolahan limbah daun kelapa sawit terhadap kandungan gizi dan kecernaan secara in-vitro. J. IlmuIlmu Pertanian Indonesia No 2: 139144

Nurhaita, N. Jamarun, R. Saladin, L Warly dan Mardiati Z, 2008. Efek suplementasi mineral Sulfur dan Phospor pada daun sawit amoniasi terhadap kecernaan zat makanan secara in-vitro dan karakteristik cairan rumen. J. Pengembangan Peternakan Tropis 33(1): 51-58

Nurhaita, N Jamarun, L Warly, dan M, Zain. 2010. Kecernaan Ransum Domba Berbasis Daun Sawit Teramoniasi Yang Disuplementasi Sulfur, Fosfor, Dan Daun Ubi Kayu. Jurnal Media Peternakan. Vol 33 No 3

Nurhaita, Ruswendi, dan Wismalinda R. 2011. Pemanfaatan Limbah Pelepah Sawit Untuk Pakan Komplit Sapi Potong Dengan Suplementasi Nutrient Precursor Mikroba Rumen. Laporan Penelitian KKP3T, Badan Litbang Pertanian Jakarta dan Fakultas Pertanian Universitas Muhammadiyah Bengkulu.

Nurhaita., Ruswendi., Wismalinda R. dan Robiyanto. 2014. Pemanfaatan Pelepah Sawit Sebagai Sumber Hijauan dalam Ransum Sapi Potong. Jurnal pastura Vol. 4 No. 1 : 38 - 41 
Nurhaita, N. Definiati and Suliasih. 2016. Fermentation with local microorganism to improve pod cocoa quality as ruminants feed In: Proc. ISEPROLOCAL. Badan Penerbitan FakultasPertanian Universitas Bengkulu, Bengkulu, Indonesia pp 218-221

Pamungkas, W. 2011. Teknologi Fermentasi, Alternatif Solusi dalam Upaya Pemanfaatan Bahan Pakan Lokal. J. Media Akuakultur Vol. 6 (1) :43-48

Saono, S. 1988. Pemanfaatan Jasad Renik dalam Pengolahan Hasil Sampingan
Produksi Pertanian. Berita LIPI, 18

Utomo, B.N. dan E. Widjaja. 2004. Limbah padat pengolahan minyak sawitsebagai sumber nutrisi ternak ruminansia. Jurnal Penelitian danPengembangan Pertanian 23(1):22-28. Badan Penelitian danPengembangan Pertanian. Departemen Pertanian. Bogor.

Winarno, F. G., S. Fardiaz and D. Fardiaz. 1980. Pengantar Teknologi Pangan. PT. Gramedia. Jakarta. 